\title{
Book Review: Surgical Instruments from Allianoi
}

\author{
Ergün Karaca
}

Department of Archeology, Trakya University School of Letters, Edirne, Turkey

D. Baykan, Surgical Instruments from Allianoi, İstanbul, 2012, Institutum Turcicum Scientiae Antiquitatis, Studia Ad Orientem Antiquum-2, 210 pages (along with the summary in English). ISBN: 978-605-4701-12-4.

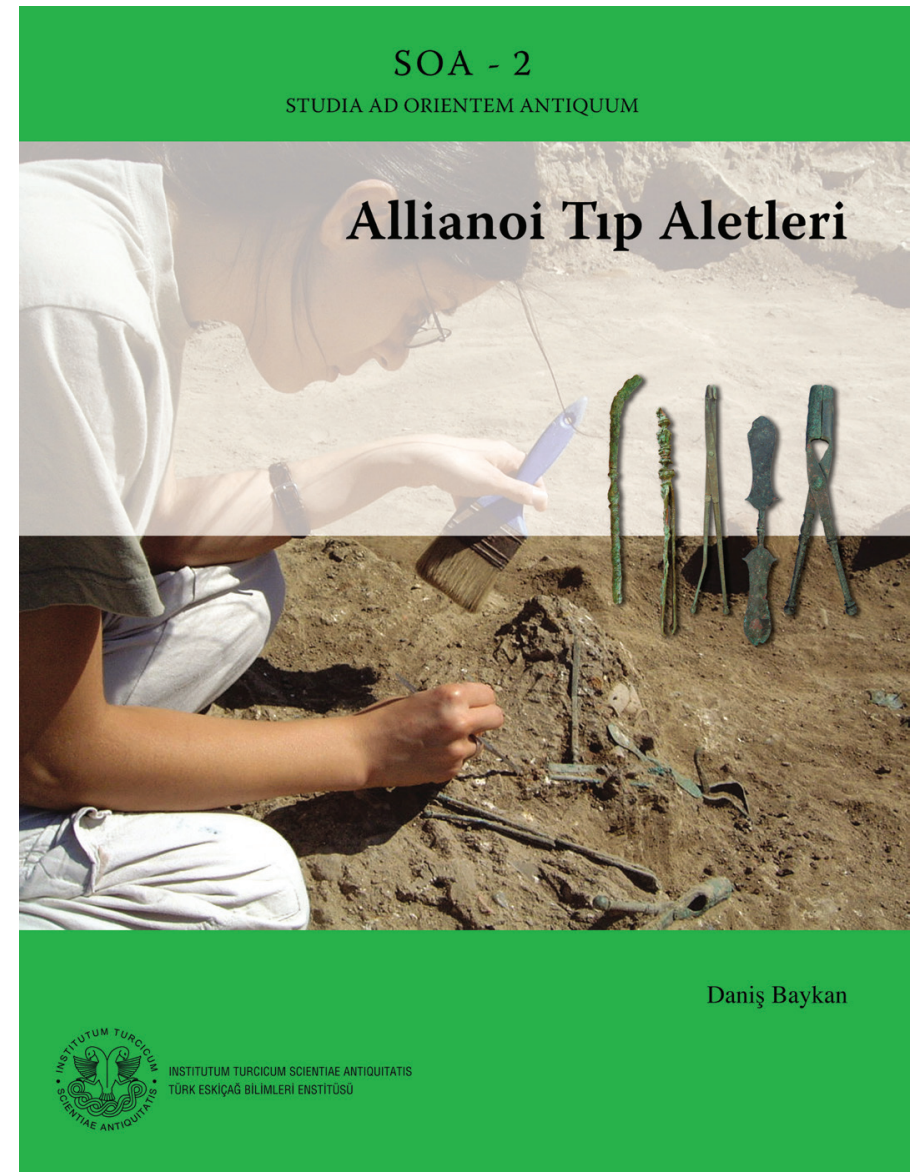

Allianoi is located at Paşa Ilıcası (The Thermal Baths of the Pasha) which is $18 \mathrm{~km}$ northeast of Bergama. Excavations for salvage work began with the construction of the Yortanlı Dam, and starting from 1998, there was a specific focus on the works in
Paşa Ilıcası at the helm of Ahmet Yaraş, However, excavation was not allowed after 2006 and the area was completely submerged in water in 2012 because of the water retention by the dam. When the surgical instruments examined by Daniş Baykan are taken into consideration, Allianoi was one of the most important medical centers belonging to the Roman Imperial period, but it was unfortunately submerged and destroyed.

The book was compiled from a doctoral dissertation titled "Surgical Instruments from Allianoi" prepared by Daniş Baykan in İstanbul University, Institute of Social Sciences, Classical Archeology Department in 2009, and it was published in 2012.

The book consists of the following parts: Foreword; Preface; Introduction; Ancient Medicine and Instruments; Allianoi (Paşa Ilıcasl); Formal and Functional Examination of Surgical Instruments in Allianoi; The Study of Allianoi Surgical Instrument Contexts; The Catalogue of the Surgical Instruments in Allainoi; Result; Summary; References; Glossary on Medical Terms; Plates and Index.

Chapter 1 is titled Ancient Medicine and Instruments (page 3-26). This chapter begins with the equivalents of currently used words "physician" or "doctor" in cultures such as Mesopotamia, Egypt, Greece, and Rome. Then, the topic is studied in different headings such as "Experiential Medicine" accomplished by learning the effect of nature on human beings; "Mystic Medicine" used for ceremonies, music, worship and talisman; "Philosophical Medicine" that is related to the theoretical causeeffect instead of the results and findings of the applications; "Scientific Medicine" that accepts chirurgia (surgery), which is based on certain rules and experiment results, as the real treatment method.

Address for Correspondence: Dr. Ergün Karaca, Department of Archeology, Trakya University School of Letters, Edirne, Turkey e-mail: ergunkaraca@gmail.com

Received: 12 April $2017 \quad$ Accepted: 20 April $2017 \cdot$ DOI: 10.4274/balkanmedj.2017.0506

Available at www.balkanmedicaljournal.org

Cite this article as:

Karaca E. Book Review: Surgical Instruments from Allianoi. Balkan Med J 2017;34:292-4

${ }^{\circ}$ Copyright 2017 by Trakya University School of Medicine / The Balkan Medical Journal published by Galenos Publishing House. 
Later, this chapter is again subdivided into parts "Written Resources, Archaeological Descriptions and Findings"; "Materials of Surgical Instruments and Their Manufacturing" and "Treatment in the Roman Period".

Written Sources, Archaeological Descriptions: This section gives information on written sources, inscriptions, archaeological findings on physicians and ancient surgical instruments. There is also information about the tombs of physicians that have the highest number of ancient surgical instruments.

Materials and Manufacturing of Surgical Instruments: It has been reported that, in ancient times, surgical instruments were made from iron, bronze, bone and other similar materials. The use of the materials mentioned in this chapter is exemplified by the findings from Allianoi.

In the rest of the chapter, the manufacturing of the instruments is covered. There is also information about "Surus Workshop" where the instruments unearthed in Pompeii were made and also the craftsmen who made the instruments in Ephesus. However, the important thing is that, inferring from the surgical instruments in Allianoi, it is suggested there may be another workshop in Allianoi. On the other hand, at the end of the chapter, the author makes various important observations about the way these instruments were manufactured under the headings "probe manufacturing", "forceps manufacturing" and "cutter manufacturing".

Treatment in the Roman Period: The physicians in the Roman period, the patients who were treated, treatment methods practiced by the physicians and where they treated the patients were studied under this heading. Besides, various information is given about military hospitals and war injuries.

Later in the chapter, under the headings "Treatment of Wounds and Removing Limbs (Amputation); "Bone and Tooth Disorders"; "Ear, Nose and Throat Diseases (Otorhinolaryngology)"; "Hemorrhoidectomy and Urology"; "Gynecological Diseases"; "Bleeding and Enema", the treatment methods of diseases in Roman period and the instruments used during these treatments are covered.

Information on the location, historical process of Allianoi (Paşa Ilicas1) where surgical instruments were found and the excavation carried out is given in Chapter 2 (pages 27-33). Furthermore, it is stated that hydrotherapy and surgical intervention were made due to the emergence of natural hot water in Allianoi (Paşa Ilicas1). In addition, the issues of the name and the location of Allianoi are discussed based on the information in the works of ancient writers, various archaeological findings related to the subject, and inscription references.

Chapter 3 is Formal and Functional Assessment of Surgical Instruments in Allianoi (pages 35-64). This section is one of the main parts of the work along with the catalog. Four hundred and twenty-eight metal surgical instruments, which were uncovered in Allianoi and are made of bronze, iron and silver, are classified as probes, forceps and cutters according to their functions and the ones that couldn't be completely described or the ones whose names are newly suggested are classified as "other instruments".

This section is divided into sub-headings "Inspection and Intervention Equipment Probes / Specillum"; "Holders / forceps"; "Cutters"; "Other Instruments".

Inspection and Intervention Materials Probes / Specillum: 292 bronze, 24 iron and two silver bronzes, a total of 298 probe / probe pieces, and broken and/or unidentifiable 9 instruments and 13 bodkins unearthed in Allianoi were examined. The probes are classified as "scoops", "hook tips", "flat tips", "needles", "cannulas" and "other probes". While the names of the instruments are given, they are given with the Ancient Greek and Latin equivalents whenever possible.

Scoops are divided into four subsections "small circular scoops", "leaf-shaped scoop", "oval scoops", "big pear-like scoops"; and cannulas are divided into two subsections, "simple cannulas" and "perforated cannulas".

Forceps: Forceps usually made of bronze are examined under the subheadings: "forceps" and "cross forceps".

Cutters: Allianoi has 12 scalpels and a handle, 13 scissors, and a handsaw. The chapter has two different sections "Scalpels and/ or Their Handles" and "Scissors". In the section about scissors, the author suggests different views on the use of 13 pieces of iron scissors in Allianoi in the Ancient Age. Regarding this, it is also very important for the author to determine and examine the use of bandages and tubes / cannulas to cut the skin.

Other Instruments: This title is divided into four subheadings: "Cautery", "Levers", "Cylindrical Boxes" and "Bleeding Cups". In the part Cautery, eleven iron instruments found in Allianoi were suggested to be cautery by the writer. These instruments are classified as disk, button, nail or lentil-shaped, brick-shaped, cutters or lancets, pyramidal tipped, and olive, spherical, nail, gamma-shaped. 8 findings in Allianoi in the part named levers were proposed as bone and tooth retractors. In the part Bleeding Cups, there is information about one bleeding cup that was badly-preserved. Another important comment in this section is Baykan's opinion on the reason why the bleeding cups are scarce in Allianoi. The author interpreted from this situation that leeches were used in Allianoi instead of bleeding. Chapter 4 of the book is titled The Study of Allianoi Surgical Instrument Contexts (pages 65-68). Some instruments whose typology and analogy were conducted are examined according to their context in this section.

On the north-western side of Allianoi, in a part of the courtyard complex which is between the bridge and the bath house (area 
b4), a context where materials are scattered around a wooden box was uncovered. According to this context, Daniş Baykan has found that this space is used for the treatment of epiglottis and hemorrhoids. It is also stated that the context in another place (area b5) to the east is related to eye surgery. According to the surgical instruments in area b7, it was found that this place was used in interventions to urology and bladder stone. Another room of the complex, area c1, was proposed as a surgical suture room. It is also suggested that the rooms on the upper floor of the hot spring in the north may also be associated with surgery. With the help of other findings, the surgical instruments in this complex are dated between the last quarter of the $1^{\text {st }}$ century $\mathrm{AD}$ and the middle of the $3^{\text {rd }}$ century AD.

Unlike the northern part, the surgical instruments in the south were found to be scattered. Here, surgical instruments that show that surgical interventions were made in area 23 in Insula 1, in the western and southern areas of the transition structure. Especially in Insula 1 area 23, instruments used in the treatment of trichiasis were found.

Daniş Baykan suggests at the end of the chapter that the density of the surgical instruments in Allinoi shows that the place where Pergamon Asklepion treated gladiators in the years 157-161/ $162 \mathrm{AD}$ with dream and psychotherapy treatment is Allianoi, especially the courtyard building complex. In addition, the discovery of defensive fractures on the skeletons unearthed in Allianoi and nearby necropolises also supports this idea.

Two hundred and forty-eight findings from Allianoi are put in order according to their functions and numerical densities in Chapter 5 Catalog of Surgical Instruments Found in Allainoi (page 69-157). In the catalog, photographs and drawings of the works are given together with the information "Name / Type
/ Material", "Measures / Finding Place and Code", "State / Description" and "Analogy / History".

In the Conclusion part (pages 159-160), while the Ancient Age, especially the Roman Period were known because of the surgical instruments found in Pompeii and the physician's graves, thanks to this study prepared by Daniş Baykan, surgical instruments of a settlement were examined in detail for the first time in Anatolia and presented to benefit of the science world. In this work, besides the known instruments, new suggestions were made about the instruments which have not been found until this study and about different uses of the known instruments in the Ancient Age. In addition, Allianoi, an important medical center, was interpreted as the place where Galenos, one of the most important physicians of the Ancient Age, performed surgical interventions.

After the conclusion part of the book, there is an extensive Summary in English (pages 161-168). Considering the whole book, it is seen that Ancient Age, Middle Age and modern sources are greatly used with 769 footnotes. At the end of the Ancient Medicine and Instruments section, the names given to ancient surgical instruments are provided in a comparative table in the languages of Turkish, Greek / Latin, Arabic / Farsi, western languages (English / French / German). Also, at the end of the chapter titled Allianoi (Paşa Ilıcası), a chronology table from $17 \mathrm{AD}$ to $551 \mathrm{AD}$ is given. There is a Glossary on Medical Terms after references. At the end of the book, the images of the topics mentioned in the text are given in the form of plates (Plate 1-22).

The book presented above is a guide to those who will study this topic as it provides the first and quite valuable commentary in the field of Anatolian archeology. 